CLINICAL STUDY

\title{
Evolution of clinical symptoms in a young woman with a recurrent gonadotroph adenoma causing ovarian hyperstimulation
}

\author{
Ivana Pentz-Vidović, Tanja Škorićㄹ, Goran Grubišić, Mirko Koršić², Tomislav Ivičević-Bakulić, \\ Nada Bešenski ${ }^{3}$, Josip Paladino ${ }^{4}$, Vesna Plavšić ${ }^{2}$ and Kamelija Žarković ${ }^{5}$ \\ Department of Gynecology and Obstetrics, Clinical Hospital 'Sestre Milosrdnice', Zagreb, Croatia, ${ }^{1}$ General Hospital Brežice, Slovenia, \\ ${ }^{2}$ Division of Endocrinology, Department of Medicine, ${ }^{3}$ Department of Radiology, ${ }^{4}$ Department of Neurosurgery and \\ ${ }^{5}$ Department of Neuropathology, University Hospital Center 'Rebro', Zagreb, Croatia \\ (Correspondence should be addressed to M Koršić, Division of Endocrinology, Department of Medicine, Clinical Hospital Center Zagreb, \\ School of Medicine University of Zagreb, Kišpatićeva 12, 10000 Zagreb, Croatia; Email: mkorsic@rebro.mef.hr)
}

\begin{abstract}
Objective: To demonstrate the clinical course in a young female with gonadotroph adenoma causing ovarian stimulation.

Patient and methods: Our patient was a 23-year-old woman with a history of oligomenorrhea who had previously undergone bilateral ovarian wedge resection owing to the clinical appearance of polycystic ovaries. Two years later, she sought treatment for headache, galactorrhea, history of spotting and lower abdominal distension. FSH, LH, $\beta$-LH, inhibin A and B, estradiol, prolactin (PRL), and $\beta$ chorionic gonadotrophin ( $\beta-\mathrm{CG}$ ) were measured, and the responses of FSH, LH and $\beta$-LH to thyrotrophin-releasing hormone (TRH) were documented. Immunohistochemical analysis of the tumor tissue was performed after surgery. Five years after the trans-sphenoidal surgery, the patient again became oligomenorrheic. A large recurrent adenoma was diagnosed on CT one year later. Transvaginal ultrasound showed ovaries of normal size with multiple small cystic formations simulating a polycystic pattern, While the patient was awaiting surgery, a pituitary apoplexy occurred. Emergency decompressive surgery was performed and the patient fully recovered.

Results: Enlarged ovaries were found on ultrasound examination simulating a hyperstimulationlike pattern. At that time, elevated levels of FSH (13.4 IU/l) and marginally elevated levels of $\beta$-LH $(1.43 \mathrm{ng} / \mathrm{ml})$ were found, whereas the level of LH $(0.5 \mathrm{IU} / \mathrm{l})$ was subnormal. Plasma estradiol was markedly supranormal $(6150 \mathrm{pmol} / \mathrm{l})$. Levels of inhibin A and B were elevated $(326 \mathrm{pg} / \mathrm{ml}$ and $588 \mathrm{pg} / \mathrm{ml}$ respectively). The prolactin level $(70 \mathrm{ng} / \mathrm{ml})$ was increased, whereas $\beta$-chorionic gonadotrophin $(\beta-C G)$ was normal. Significantly increased FSH, LH, and $\beta$-LH responses to TRH stimulation were documented. Pituitary macroadenoma was found on MRI scan and removed by trans-sphenoidal surgery. Immunohistochemical examination showed high positivity for $\beta$-CG and LH, and slight positivity for FSH. Five years after the surgery, estradiol was elevated $(1160 \mathrm{pmol} / \mathrm{l})$, whereas basal levels of LH $(4.65 \mathrm{IU} / \mathrm{l})$ and FSH (3.98 IU/l) were not suppressed. After the second operation, immunostaining of the adenoma tissue confirmed the previous findings.

Conclusions: Measurement of gonadotrophins in our case did not prove to be a method for identifying a large recurrent gonadotroph pituitary adenoma. The sonographic ovarian imaging varied from a polycystic- to an ovarian hyperstimulation-like pattern during the evolution of the tumour.
\end{abstract}

European Journal of Endocrinology 143 607-614

\section{Introduction}

Gonadotroph adenomas are generally revealed by symptoms of mass effect at the stage of macroadenoma because they secrete inefficiently. Even when they produce supranormal serum concentrations of intact gonadotrophins or their subunits, these products rarely result in a recognizable clinical syndrome (1). A small group of men with follicle-stimulating hormone (FSH)secreting tumours and bilateral testicular enlargement have previously been described $(2,3)$. Furthermore, only four cases of gonadotroph adenomas in women that resulted in ovarian hyperstimulation have been reported (4-7). The probable reason that women who have gonadotroph adenomas and supranormal FSH concentrations have not been recognized as having 
ovarian hyperstimulation is that virtually all of them are over 45 years and have ovaries depleted of preantral follicles and insensitive to FSH stimulation (4). However, other hypotheses can be postulated; for example, thorough evaluation in premenopausal women with a nonfunctioning pituitary adenoma (measurement of gonadotrophin and estrogen levels, ultrasound examination of the ovaries) is not always performed. Alternatively, the biological activity of luteinizing hormone (LH) and FSH secreted by gonadotrophinomas might be low $(3,8)$.

Although our case of gonadotroph adenoma presenting with ovarian hyperstimulation is not unique, it is interesting because of the evolution of clinical symptoms during the 8-year period.

\section{Case report}

A 23-year-old nullipara had first sought medical attention in September 1991 for irregular menstrual bleeding since the menarche, which had occurred at the age of 11.5 years. Periods of 3-4 normal menstrual cycles were interchanged with periods of several months without menstrual bleeding, during which time gestagens were administered to induce withdrawal bleeding. At that time, on the basis of clinical history of oligomenorrhea and ultrasound examination, polycystic ovaries (PCO) were misdiagnosed and a bilateral ovarian wedge resection was performed. Pathohistological examination of the ovaries revealed cysts, which measured up to $5 \mathrm{~cm}$, consisting of follicular and partly luteinized follicular epithelium. A day after the ovarian wedge resection spontaneous galactorrhea appeared for the first time and in the next 4 months her menses, which had resumed after the ovarian wedge resection, stopped abruptly. Galactorrhea was treated using bromocriptine ( $5 \mathrm{mg}$ daily) and uterine bleeding was induced by dydrogesteron (10 mg daily) for 5 days each month, which resulted in regular uterine bleeding. This therapy was administered for 1.5 years. The patient had stopped therapy 3 months before the first admission to our Department in January 1993.

At that time, she was complaining of galactorrhea and spotting over the last 3-month period, as well as of headache and a sensation of fullness in the lower abdomen. Physical examination showed galactorrhea after mammary expression while gynaecological examination revealed enlarged ovaries. Transvaginal ultrasound examination demonstrated multicystic ovaries and thickened endometrium, measuring $12 \mathrm{~mm}$ at its widest point. The right ovary measured $8 \times 7 \times 6 \mathrm{~cm}$ and contained five cysts of up to $5 \mathrm{~cm}$ in diameter, while the left ovary measured $8 \times 9 \times 5 \mathrm{~cm}$ and also contained five cysts of up to $4 \mathrm{~cm}$ in diameter (Fig. 1). MRI scan showed pituitary macroadenoma $(28 \times 20 \mathrm{~mm})$ with suprasellar extension causing compression of the optic chiasm (Fig. 2). The visual field examination revealed bitemporal hemianopsia. Endocrinological examination

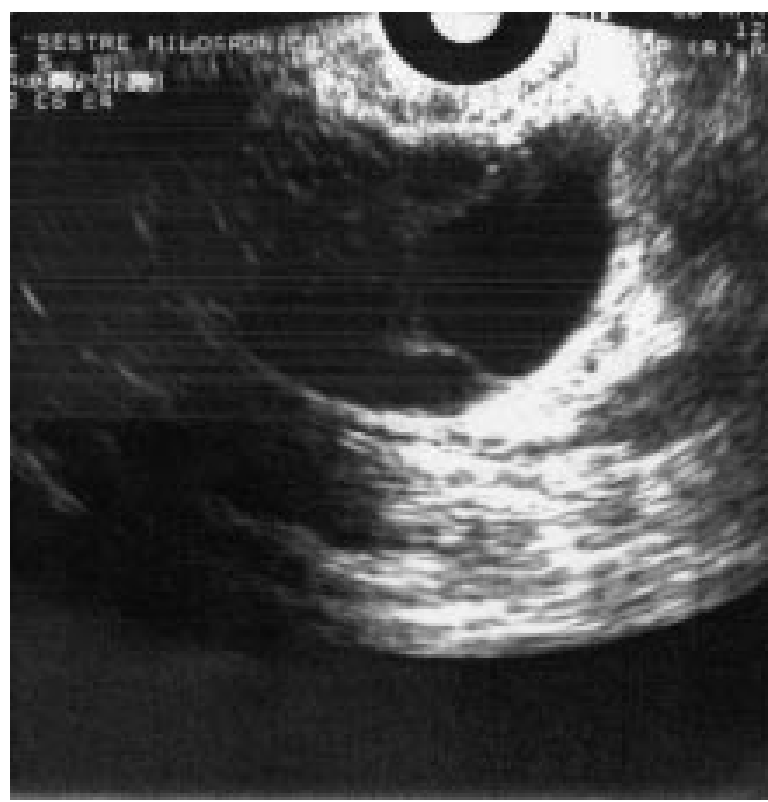

Figure 1 Transvaginal sonographic image of enlarged ovary with multiple cysts up to $5 \mathrm{~cm}$ in diameter.

showed elevated serum basal levels of FSH (13.4 IU/l) and marginally elevated $\beta-\mathrm{LH}(1.43 \mathrm{ng} / \mathrm{ml})$, but subnormal levels of LH $(0.5 \mathrm{IU} / \mathrm{l})$. Serum levels of estradiol $(6150 \mathrm{pmol} / \mathrm{l})$ were markedly elevated. Levels of

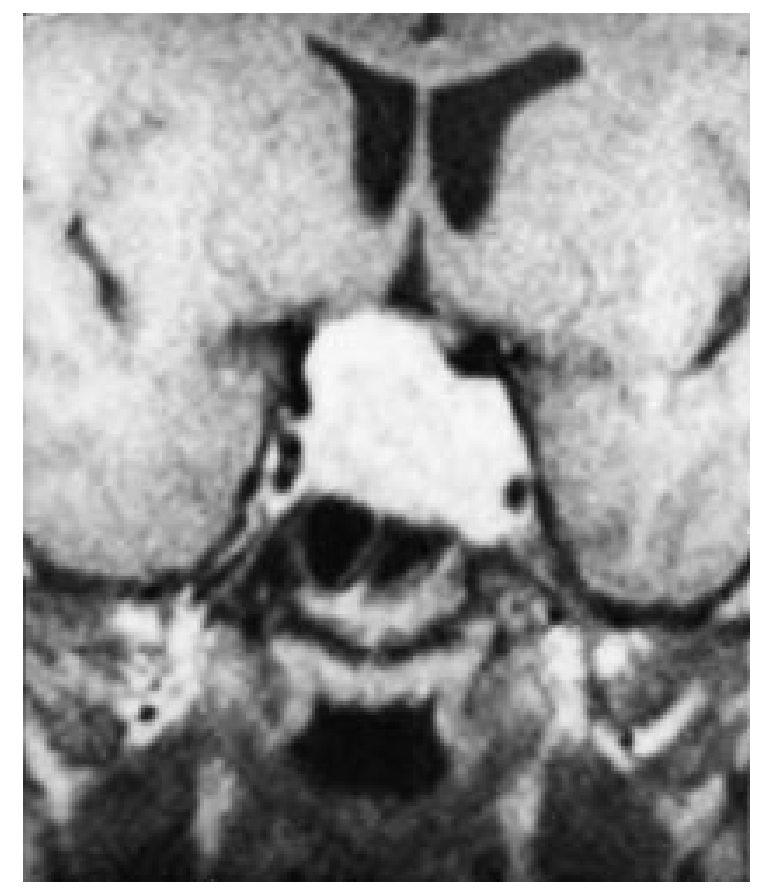

Figure $2 \mathrm{MRI}$ shows macroadenoma $(28 \times 20 \mathrm{~mm})$ with suprasellar extension causing the compression of the optic chiasm on the right and extension into the left cavernous sinus. 
Table 1 Hormone values before and 3 months after the trans-sphenoidal surgery and 2 months before the apoplexy in a patient with gonadotroph adenoma.

\begin{tabular}{|c|c|c|c|}
\hline Hormones & $\begin{array}{c}\text { Before the trans-sphenoidal } \\
\text { surgery } \\
\text { (reference values) }\end{array}$ & $\begin{array}{c}3 \text { months after trans-sphenoidal } \\
\text { surgery } \\
\text { (reference values) }\end{array}$ & $\begin{array}{c}2 \text { months before apoplexy } \\
\text { (reference values) }\end{array}$ \\
\hline LH (IU/I) & $\begin{array}{l}0.5 \\
\text { (fp and Ip 1.5-20, ov 17-80) }\end{array}$ & $\begin{array}{l}4.03 \\
\text { (fp and Ip 0.8-10.2, ov 20-50) }\end{array}$ & $\begin{array}{l}4.65 \\
\text { (fp and Ip 0.8-10.2, ov 20-50) }\end{array}$ \\
\hline FSH (IU/I) & $\begin{array}{l}13.4 \\
\text { (fp and Ip 1-10, ov 6-22) }\end{array}$ & $\begin{array}{l}3.48 \\
\text { (fp and Ip } 0.7-7.9, \text { ov } 3-15 \text { ) }\end{array}$ & $\begin{array}{l}3.98 \\
\text { (fp and Ip 0.7-7.9, ov 3-15) }\end{array}$ \\
\hline$\beta$-LH (ng/ml) & $\begin{array}{l}1.43 \\
(<1.33)\end{array}$ & - & - \\
\hline$\alpha$-SU (IU/I) & $\begin{array}{l}0.14 \\
(<0.9)\end{array}$ & - & - \\
\hline PRL (ng/ml) & $\begin{array}{l}70 \\
(3.6-18.9)\end{array}$ & $\begin{array}{l}20.3 \\
(3.6-18.9)\end{array}$ & $\begin{array}{l}12.9 \\
(3.6-18.9)\end{array}$ \\
\hline Estradiol (pmol/l) & $\begin{array}{l}6150 \\
(f p 184-574, \text { Ip 389-984) }\end{array}$ & $\begin{array}{l}290 \\
(f p 36-730, \text { Ip 50-950) }\end{array}$ & $\begin{array}{l}1160 \\
(f p 36-730, \text { Ip 50-950) }\end{array}$ \\
\hline Progesterone (nmol/l) & $\begin{array}{l}11.7 \\
\text { (fp } 0.3-2.5, \text { Ip 16.2-76.3) }\end{array}$ & $\begin{array}{l}1.45 \\
\text { (fp } 0.54-4.96, \text { Ip } 5.1-100.8)\end{array}$ & $\begin{array}{l}0.98 \\
(\text { fp } 0.54-4.96, \text { Ip 5.1-100.8) }\end{array}$ \\
\hline 17-OH-progesterone (nmol/l) & $\begin{array}{l}8.3 \\
(\text { fp } 0.7-3.2, \text { Ip } 1.8-10.3)\end{array}$ & - & $\begin{array}{l}1.41 \\
(0.3-15)\end{array}$ \\
\hline Testosterone (nmol/l) & $\begin{array}{l}2.9 \\
(0.7-2.5)\end{array}$ & $\begin{array}{l}1.59 \\
(0.7-2.8)\end{array}$ & $\begin{array}{l}0.63 \\
(0.7-2.8)\end{array}$ \\
\hline Androstendione (nmol/l) & $\begin{array}{l}9.72 \\
(1.99-9.25)\end{array}$ & - & - \\
\hline DHEA-S $(\mu \mathrm{mol} / \mathrm{l})$ & $\begin{array}{l}5.44 \\
(0.95-11.67)\end{array}$ & - & $\begin{array}{l}2.25 \\
(0.9-11.6)\end{array}$ \\
\hline
\end{tabular}

fp, follicular phase; Ip, luteal phase; ov, ovulation.

testosterone, androstendione, progesterone, 17-OHprogesterone and prolactin (PRL) were also increased (Table 1). The levels of inhibin A and B were $326 \mathrm{pg} / \mathrm{ml}$ and $588 \mathrm{pg} / \mathrm{ml}$ respectively (normal values $<60 \mathrm{pg} / \mathrm{ml}$ and $<130 \mathrm{pg} / \mathrm{ml}$ respectively). Luteinizing hormonereleasing hormone (LHRH)- and thyrotrophin-releasing hormone (TRH)-stimulation tests were performed (Table 2). $\beta$-Chorionic gonadotrophin $(\beta-C G)$ was $<5 \mathrm{IU} / \mathrm{l}$ (normal values < $5 \mathrm{IU} / \mathrm{l}$ ). Basal serum thyrotrophin (TSH) was $0.3 \mathrm{mIU} / \mathrm{l}$ (normal range $0.45-$ $3.29 \mathrm{mIU} / \mathrm{l}$ ) but responded normally to TRH stimulation. Basal levels of thyroxine (T4) and tri-iodothyronine

Table 2 Results of LHRH and TRH tests before the transsphenoidal surgery in a patient with gonadotroph adenoma.

\begin{tabular}{llc}
\hline & $\begin{array}{l}\text { LHRH }(100 \mu \text { g i.v.) } \\
\text { Basal } \rightarrow \text { max. (\%) }\end{array}$ & $\begin{array}{c}\text { TRH }(200 \mu \text { g i.v. }) \\
\text { Basal } \rightarrow \text { max. }(\%)\end{array}$ \\
\hline FSH (IU/I) & $13.4 \rightarrow 13.8(3 \%)$ & $13.8 \rightarrow 24.9(81 \%)$ \\
$\mathrm{LH} \mathrm{(IU/l)}$ & $0.54 \rightarrow 4.13(660 \%)$ & $0.5 \rightarrow 0.8(59 \%)$ \\
$\beta-\mathrm{LH}(\mathrm{ng} / \mathrm{ml})$ & - & $1.43 \rightarrow 2.96(107 \%)$ \\
$\alpha-\mathrm{SU}(\mathrm{IU} / \mathrm{l})$ & $0.12 \rightarrow 0.22(80 \%)$ & $0.16 \rightarrow 0.17(6 \%)$ \\
\hline
\end{tabular}

Reference values: $\alpha$-SU $<0.9 \mathrm{IU} / \mathrm{l} ; \beta$-LH $<1.33 \mathrm{ng} / \mathrm{ml}$; LH fp and Ip 1.5-20 IU/l, ov, 17-80 IU/l; FSH fp and Ip 1-10 IU/I, ov 6-22 IU/I. fp, follicular phase; Ip, luteal phase; ov, ovulation.
(T3) were $1.4 \mathrm{nmol} / \mathrm{l}$ (normal range $1.2-2.8 \mathrm{nmol} / \mathrm{l}$ ) and $96 \mathrm{nmol} / \mathrm{l}$ (normal range $70-165 \mathrm{nmol} / \mathrm{l}$ ) respectively. Basal levels of growth hormone $(\mathrm{GH})$, adrenocorticotrophin (ACTH) and cortisol were normal, as well as their responses to stimulation tests.

The pituitary adenoma was trans-sphenoidally removed. Immunohistochemistry was markedly positive for $\beta$-human $\mathrm{CG}$ and $\mathrm{LH}$, and only slightly for FSH $(<5 \%$ of cells). Electron microscopy revealed that some of the adenoma cells contained numerous secretory granules ranging from 150 to $300 \mathrm{~nm}$ in diameter lined up along cell membrane, whereas in most of the adenoma cells, secretory granules were sparse. Numerous mitochondria and well-developed lamelar rough endoplasmic reticulum (RER) were found (Fig. 3).

The patient's menstrual cycle resumed 2 months after the surgery. Three months later (July 1993), circulating $\mathrm{FSH}$ levels decreased to $3.48 \mathrm{IU} / \mathrm{l}$, while $\mathrm{LH}$ increased to $4.03 \mathrm{IU} / \mathrm{l}$, and both responded to $\mathrm{LHRH}$ stimulation (an increase of $107 \%$ and $450 \%$ respectively). Estradiol, testosterone, progesterone and 17-OHprogesterone levels normalized (Table 1). Basal levels of all the other pituitary hormones were also normal. Her menses again became irregular in 1997.

In January 1999, the patient was evaluated because she was unable to conceive. She was oligomenorrheic 

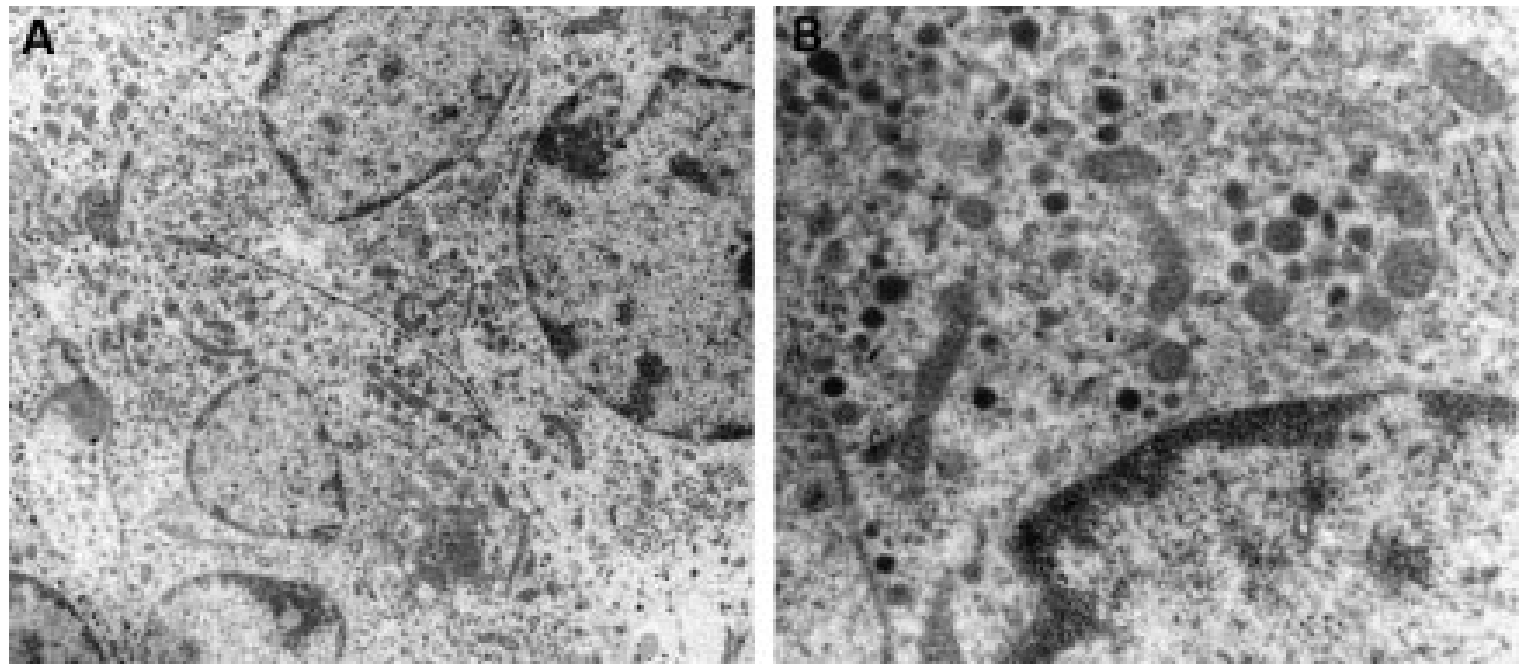

Figure 3 Electron microscopy of the adenoma. (A) Some of the adenoma cells containing numerous granules ranging from 150 to $300 \mathrm{~nm}$ in diameter line up along the cell membrane, whereas in most of the adenoma cells granules are sparse $(\times 5700)$. $(B)$ Numerous mitochondria and well-developed lamellar RER are seen $(\times 12250)$.

(40 \pm 5 days) during the previous year. Basal levels of LH and FSH were normal, while estradiol levels were elevated (Table 1). Levels of TSH, T3 and T4 were $1.52 \mathrm{mIU} / \mathrm{l}$ (normal range $0.5-4.2 \mathrm{mIU} / \mathrm{l}$ ), $1.6 \mathrm{nmol} / \mathrm{l}$ (normal range $1.3-2.5 \mathrm{nmol} / \mathrm{l}$ ) and $128 \mathrm{nmol} / \mathrm{l}$ (normal range $70-165 \mathrm{nmol} / \mathrm{l}$ ) respectively. The basal GH level was $10 \mathrm{mIU} / \mathrm{l}$ (normal range $<0.25-20 \mathrm{mIU} / \mathrm{l}$ ). Transvaginal ultrasound examination demonstrated normal size ovaries with multiple follicles up to $1 \mathrm{~cm}$

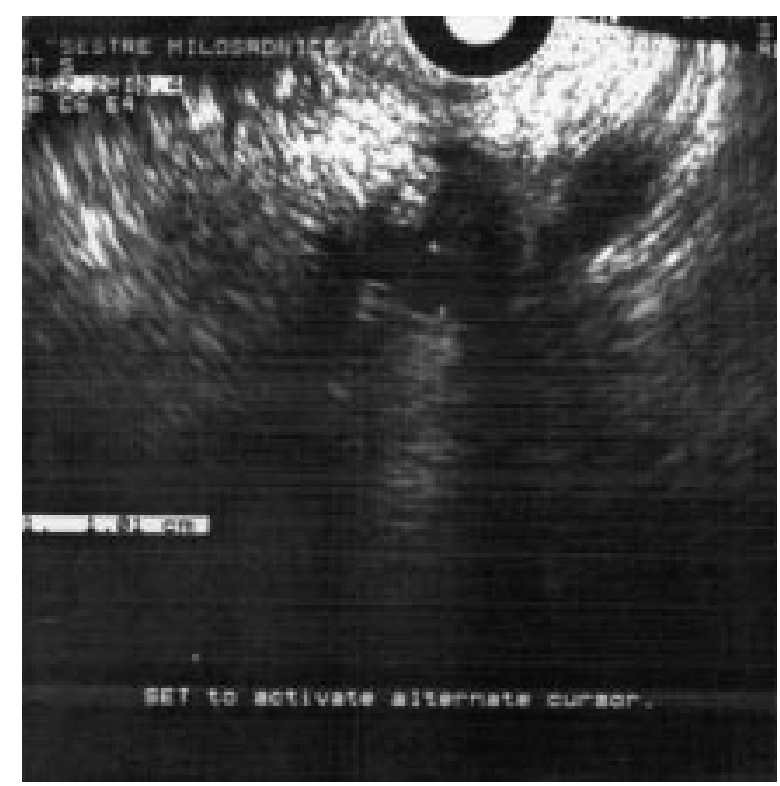

Figure 4 Transvaginal sonographic image of the normal size ovary showing multiple small follicles measuring from 1 to $1.5 \mathrm{~cm}$ in diameter within the ovary. in diameter (Fig. 4). CT scan showed a large recurrent tumor, measuring $25 \mathrm{~mm}$ in diameter, extending suprasellary and into the left cavernous sinus. The tumour caused compression of the optic chiasm on the left side (Fig. 5). While the patient was waiting for surgical treatment, macroadenoma apoplexy occurred resulting in a sudden onset of severe headache, vomiting, left eye blindness and disturbance of consciousness. Decompressive emergency transcranial surgery was performed and a large necrotic tumour was removed. The patient fully recovered and her eyesight was preserved.

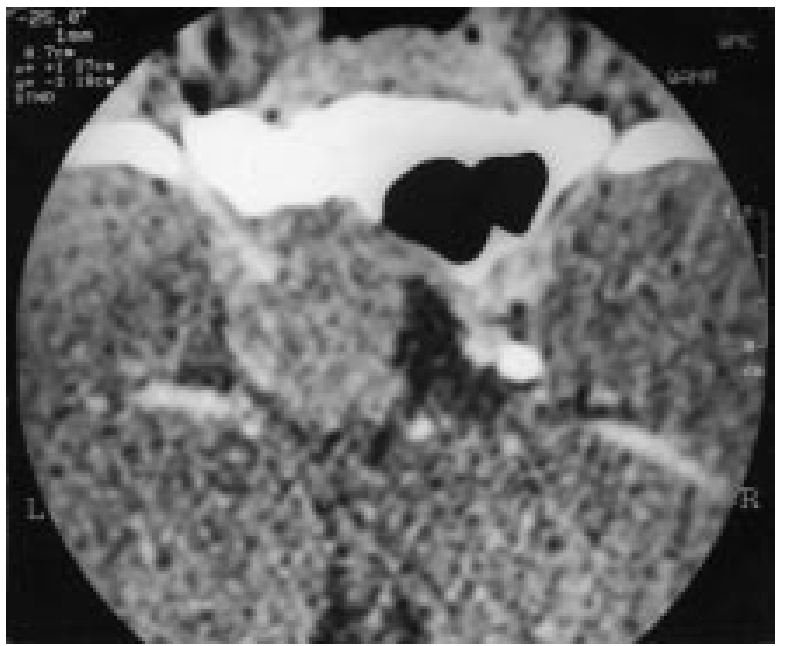

Figure 5 The recurrent tumour on the left side with deformation of the suprasellar system demonstrated by coronal CT scan. 

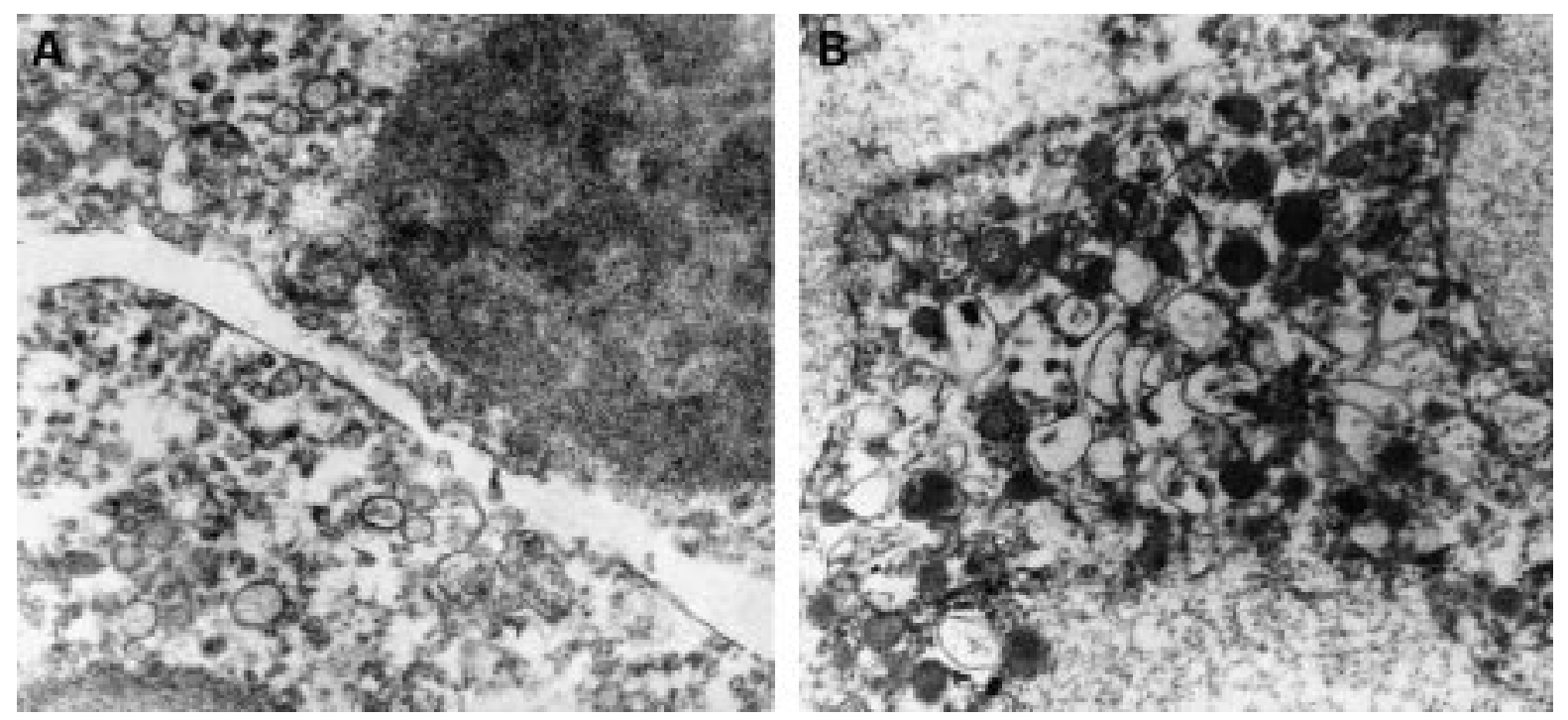

Figure 6 Electron microscopy of the recurrent adenoma tissue. (A) Sparse ballooned mitochondria with destroyed cristae, numerous secretory granules $(300 \mathrm{~nm})$, and an increased number of sacular RER are seen in some sublethally injured cells $(\times 19000)$. (B) In some cells a 'honeycomb' appearance consisting of round formations reminiscent of Golgi apparatus are evident (×23750).

Immunohistochemical findings were consistent with those after the trans-sphenoidal operation. Electron microscopy showed cytolysis and karyolysis that occurred after haemorrhagic necrosis in most of the cells. In some sublethally injured cells, sparse ballooned mitochondria with destroyed cristae, numerous secretory granules $(300 \mathrm{~nm})$ and an increased number of saccular RER were found. In some cells a 'honeycomb' appearance consisting of round formations reminiscent of Golgi apparatus were seen (Fig. 6). LH and FSH were secreted in cell cultures of the adenomatous tissue obtained at both neurosurgical procedures.

\section{Materials and methods}

\section{Hormone assays}

LH and FSH, before the trans-sphenoidal surgery, were measured by immunoradiometric assay (IRMA) (Sorin Biomedica, Saluggia, Italy). Detection limits were $0.25 \mathrm{IU} / \mathrm{l}$ for $\mathrm{LH}$ and $0.15 \mathrm{IU} / \mathrm{l}$ for FSH. After the transsphenoidal surgery, the levels were measured by immunoenzymometric assay with a luminiscent substrate (Ortho-Clinical Diagnostics, a Johnson \& Johnson Company, Amersham, UK); detection limits were $0.12 \mathrm{IU} / \mathrm{l}$ and $0.05 \mathrm{IU} / \mathrm{l}$ for $\mathrm{LH}$ and FSH respectively. The standards used were WHO 2nd IS 80/562 for LH, and WHO 2nd IRP 78/549 for FSH. PRL was determined by IRMA (Diagnostic Products Corporation, Los Angeles, CA, USA). The detection limit was $0.1 \mathrm{ng} /$ $\mathrm{ml}$. TSH was measured by IRMA (Ortho-Clinical Diagnostics). The analytical sensitivity of the assay was $0.04 \mathrm{mIU} / \mathrm{l}$, while functional sensitivity was
$0.2 \mathrm{mIU} / \mathrm{l} . \alpha$-Subunit of glycoprotein hormones ( $\alpha$-SU) was measured by IRMA (Immunotech International, Marseilles, France). The detection limit was $0.025 \mathrm{IU} / \mathrm{l}$. Cross-reactions with LH, FSH and TSH were less than $0.1 \%$. $1 \mathrm{IU} / \mathrm{l}$ of $\alpha$-SU corresponds to a concentration of $1 \mathrm{ng} / \mathrm{ml}$. $\beta$-LH was measured using an in-house RIA method (reagents from NIH, Bethesda, MD, USA). $\beta$-LH was iodinated by the chloramine T method. Antiserum was used at a final dilution of 1:60 000. The detection limit was $0.1 \mathrm{ng} / \mathrm{ml}$. Intra- and interassay coefficients of variation were $6.7 \%$ and $18.8 \%$ respectively. Crossreactions with $\mathrm{LH}$ and FSH were $15 \%$ and $0.32 \%$ respectively. Serum inhibin A and B were measured at the Laboratory for Clinical Pathology (Antwerp, Belgium) (9). $\beta$-CG was measured by a two-site IRMA (Kabi Pharmacia Diagnostics, Uppsala, Sweden). The detection limit was $0.4 \mathrm{U} / \mathrm{l}$. Before the first adenomectomy, progesterone and estradiol were measured by RIA (CIS Bio International, Yvette Cedex, France). Detection limits were 0.6 and $0.02 \mathrm{nmol} / \mathrm{l}$ for progesterone and estradiol, respectively. After the trans-sphenoidal surgery, they were further assayed (reagents obtained from Diagnostic Products Corporation). Detection limits were $0.1 \mathrm{nmol} / \mathrm{l}$ for progesterone and $0.02 \mathrm{nmol} / \mathrm{l}$ for estradiol. Androstendione and dehydroepiandrosterone sulphate (DHEA-S) were measured by RIA (Diagnostic Systems Laboratories, Webster, TX, USA). Detection limits were $0.07 \mathrm{nmol} / \mathrm{l}$ and $0.04 \mu \mathrm{mol} / \mathrm{l}$ for androstenedione and DHEA-S, respectively. Testosterone was measured by RIA (Byk-Sangtec Diagnostica, Germany). The detection limit was $0.1 \mathrm{nmol} / \mathrm{l}$.

For the LHRH and TRH tests, $100 \mu \mathrm{g}$ LHRH and $200 \mu \mathrm{g}$ TRH (Relefact, Hoechst, Frankfurt/Main, Germany), respectively, were administered intravenously. 
The maximal response to test substances was calculated as follows: (maximal response - mean basal value) $\times 100 /$ mean basal value $(10)$.

\section{Morphological and cell culture studies}

The cell cultures were prepared as previously described (10).

For light microscopy, tumour tissue was fixed in 10\% buffered formalin and embedded in paraffin. Formalinfixed, paraffin-embedded (FFPE) sections of $3 \mathrm{~mm}$ thickness were stained with haematoxylin-eosin and the periodic acid Schiff method. Antiserum samples were applied to detect the following hormones: GH (1:500 dilution); PRL (1:250 dilution); TSH (1:600 dilution); ACTH (1:250 dilution); LH (1:800 dilution, polyclonal antibody); FSH (1:150 dilution, monoclonal antibody; DAKO Corporation, Carpinteria, CA, USA); and $\beta-\mathrm{CG}$ (1:200 dilution, DAKO A/S, Glostrup, Denmark). Sections were stained by the peroxidase-antiperoxidase (PAP) technique. For electron microscopy, tissue was fixed in $2.5 \%$ glutaraldehyde, postfixed in $1 \%$ osmium tetroxide, dehydrated, and embedded in an epoxy resin mixture (Serva, Heidelberg, Germany). Appropriate areas were selected on toluidine blue semi-thin sections for the ultrastructural study. Ultra-thin sections (15$20 \mathrm{~nm}$ ) were stained with uranyl acetate and lead citrate and examined with a 9S-2 electron microscope (Carl-Zeiss, Oberkochen, Germany).

\section{Discussion}

The gonadotroph adenoma in our patient was first suspected on the basis of ultrasound examination of the ovaries and increased basal levels of FSH and estradiol. High FSH levels resulted in the formation of multiple large ovarian cysts and significantly increased the production of estradiol, which caused endometrial hyperplasia. Four cases of gonadotroph adenomas in women that resulted in ovarian hyperstimulation have already been reported (4-7). Three of these secreted FSH (4-6), whereas the fourth secreted FSH and LH (7). Estradiol levels were elevated in all cases; in the case of Christin-Maitre et al. the levels were extremely high (7). Consistent with the two cell-two gonadotrophin model, ovarian estrogen secretion occurs only if both FSH and LH are present simultaneously (9). Decreased basal LH levels in patients with gonadotroph adenomas have been attributed to the impairment of normal pituitary tissue by the adenoma or, alternatively, to the elevated estrogen levels that might have suppressed gonadotrophin secretion from the normal pituitary $(4,5)$. Other pathophysiological mechanisms have been proposed; for example, hypersecretion of an abnormal form of FSH in a woman with pituitary adenoma suppressed the secretion of both FSH and LH from normal gonadotrophs, presumably by inhibiting the LHRH receptors of the pituitary or by inhibiting
LHRH secretion from the hypothalamus (11). Woolf \& Schenk demonstrated LH production by an FSHsecreting tumour in tissue culture; the amount of LH secreted in vitro was 10-times lower than that of FSH (12). In our patient, the finding of LH immunologically within the tumour tissue and in the adenoma cell culture suggest that LH was produced and probably secreted by the tumour (13). The paradoxical response of LH to TRH stimulation in vivo is further evidence that supports LH secretion by the gonadotroph adenoma $(14,15)$. Following LHRH administration, a markedly increased LH response was seen. Snyder (16) and White et al. (17) showed a doubling of LH concentration following administration of gonadotrophin-releasing hormone in $17 / 23$ and in 5/9 patients with gonadotrophin-secreting tumours respectively; however, in their cases basal concentrations of LH were normal or elevated. In our patient, the $\alpha$-subunit also increased significantly after LHRH stimulation, but $\beta$-LH was not measured. On the other hand, there was no increase in FSH concentration after LHRH stimulation, which is consistent with the hypothesis of autonomous tumour secretion of FSH (13).

In addition to positive immunostaining for $\mathrm{LH}$, only slight positivity for FSH in the adenoma tissue was found, which is consistent with the relatively low peripheral FSH levels in the presence of a large adenomatous mass (18). Alternatively, heterogeneity of intact FSH or different isoforms of FSH in pituitary tumours could account for the negative FSH staining (8). Furthermore, positivity for $\beta$-CG was found. Highly positive LH immunostaining of the adenomatous tissue which was found in the presence of subnormal serum $\mathrm{LH}$ levels is most probably due to using an LH polyclonal antiserum with high cross-reactivity for $\beta$-CG (40\%).

Before the trans-sphenoidal surgery, increased levels of inhibin $\mathrm{B}$ were produced by the cohort of recruited follicles under FSH control. Production of inhibin A was also increased, which indicates luteinization of follicles (7). The increased progesterone level could only be explained by LH stimulation, although serum levels of LH were subnormal. Furthermore, androstendione and testosterone were also slightly elevated. While thecal androgen production is exquisitely sensitive to LH, plasma LH concentration in our patient was sufficient to maintain plasma androstenedione concentration (19). Interestingly, inhibin may regulate follicular maturation, particularly in immature follicles, by stimulating theca cell androgen production (20).

Concerning the differences between the clinical presentation in the previously reported cases of gonadotrophinoma with ovarian hyperstimulation, in two cases amenorrhea/oligomenorrhea were present $(4,6)$, while in the third the cause of emergency hospitalisation was massive metrorrhagia (7). In our patient, as well as in the case of Valimaki et al. (5), prolonged spotting (light in quantity and flow) was probably due to relatively insufficient progesterone production in the presence of 
an enormous amount of estradiol. The same situation may be seen with luteal phase inadequacy and decreased progesterone effects on the endometrium that leads to incomplete breakdown of the endometrium and prolonged dysfunctional uterine bleeding.

Galactorrhea appeared for the first time a day after the bilateral ovarian wedge resection. We assume that the reduction of ovarian mass, which had caused the decrease in estrogen and progesterone levels, was a trigger for the appearance of galactorrhea as in the case of normal postpartum galactorrhea or after the discontinuation of oral contraceptives (21). Later, gallactorrhea persisted, probably due to the mass effect of the adenoma, although supranormal serum estradiol level may have also been the reason for the elevated PRL (4). Furthermore, lower concentration of estrogen after the bilateral ovarian wedge resection could result in decreased inhibitory effect on FSH secretion by the adenoma. Valimaki et al. reported that in their patient with gonadotroph adenoma and ovarian hyperstimulation symptoms developed after cessation of the use of contraceptive pills containing ethynil estradiol and progestin. They suggested that ethynil estradiol in combination with progestin was more potent than natural estrogens in suppressing the production of FSH by the pituitary tumour, thus preventing the disease from becoming symptomatic (5).

Three months after the trans-sphenoidal surgery, a complete recovery of pituitary function occurred in our patient. Normal responses of LH and FSH to LHRH stimulation were seen. Furthermore, completely normal basal levels of all pituitary hormones were found after 6 years when a large recurrent tumour was present. Some limitations in interpretation of the serum gonadotrophin levels are due to the fact that different assays were used, but it should be pointed out that the methods had no cross-reactivity and the results are therefore comparable (of course in the respective normal ranges). Concentration of estradiol was again elevated, despite the normal basal LH and FSH levels. Considering the long half-life of FSH in blood, it seems less probable that we failed to detect increased levels of FSH if the sera were accidentally taken between the FSH pulses (17). It is obvious that the recurrent tumour did not secrete FSH at such levels as before, although morphology was not significantly different in comparison to the adenoma from the first operation. Discrepancies in gonadotrophin levels during the evolution of the pituitary adenoma may be also due to the fact that the investigations were carried out at different stages of the disease (11). When the recurrent pituitary adenoma was diagnosed, ultrasound examination revealed PCO. Sullivan et al. demonstrated that there were no significant differences in the number of follicles ( $14 \mathrm{~mm}$ or more in diameter) between the groups of patients receiving only recombinant FSH or combined FSH and $\mathrm{LH}$ and that serum estradiol concentrations have to be used as an index of follicular development (19). Levels of estradiol in our patient before the apoplexy were elevated but not as high as before the trans-sphenoidal surgery. It is possible that, early in the patient's history, the illness followed the same pattern, so that PCO was initially diagnosed.

\section{Acknowledgements}

The authors would like to express their sincere gratitude to Mrs Annie Vereecken (Laboratory for Clinical Pathology, Antwerpen, Belgium) for measuring inhibins and to Dr Parlow (National Pituitary Agency, National Institutes of Health, Bethesda, MD, USA) for providing the $\beta$-LH antisera and reagents (AFP-3477A). The work was sponsored by the Croatian Ministry of Science (Project No.108116).

\section{References}

1 Snyder PJ. Gonadotroph adenomas. Journal of Clinical Endocrinology and Metabolism 199580 1059-1061.

2 Heseltine D, White MC, Kandall-Taylor P, De Kretser DM \& Kelly W. Testicular enlargement and elevated serum inhibin concentrations occur in patients with pituitary macroadenomas secreting FSH. Clinical Endocrinology 198931 411-423.

3 Pigny P, Henric B, Lahlou N, Christin S \& Mazzuca M. A gonadotroph adenoma with a high proportion of basic FSH isohormones by chromatofocusing. Journal of Clinical Endocrinology and Metabolism 199681 2407-2408.

4 Djerassi A, Coutifaris C, West VA, Asa SL, Kapoor SC, Pavlou SN et al. Gonadotroph adenoma in a premenopausal woman secreting follicle-stimulating hormone and causing ovarian hyperstimulation. Journal of Clinical Endocrinology and Metabolism $199580591-594$.

5 Valimaki MJ, Tiitinen A, Alfthan H, Paetau A, Poranen A, Sane T et al. Ovarian hyperstimulation caused by gonadotroph adenoma secreting follicle-stimulating hormone in 28-year-old woman. Journal of Clinical Endocrinology and Metabolism 199984 4204-4208.

6 Catargi B, Felicie-Dellan E \& Tabarin A. Comment on gonadotroph adenoma causing ovarian hyperstimulation. Journal of Clinical Endocrinology and Metabolism 1999843404.

7 Christin-Maitre S, Rongieres-Bertrand C, Kottler M, Lahlou N, Frydman R, Touraine P et al. A spontaneous and severe hyperstimulation of the ovaries revealing a gonadotroph adenoma. Journal of Clinical Endocrinology and Metabolism $1998 \mathbf{8 3}$ 3450-3453.

8 Chappel SC, Bashey HM \& Snyder PJ. Similar isoelectric profiles of FSH from gonadotroph cell adenomas and non-adenomatous pituitaries. Acta Endocrinologica 1986113 311-316.

9 Renier MA, Vereecken A \& Van Herck E. Dimeric inhibin serum values as markers of ovarian activity in pill-free intervals. Contraception 199857 45-48.

10 Plavšić V, Koršić M, Žarković N, Rogić D, Žarković K, Giljević Z et al. Glycoprotein hormone alpha-subunit release in sera and tumour cell cultures and the responses to thyrotropin-releasing hormone in the patients with clinically nonfunctioning pituitary adenomas. Clinical Laboratory 199642 285-289.

11 Wide L \& Lundberg PO. Hypersecretion of an abnormal form of follicle stimulating hormone associated with suppressed luteinizing hormone secretion in a woman with pituitary adenoma. Journal of Clinical Endocrinology and Metabolism 1981 52 923-930.

12 Woolf PD \& Schenk EA. An FSH-producing pituitary tumor in a patient with hypogonadism. Journal of Clinical Endocrinology and Metabolism $197438561-568$. 
13 Friend JN, Judge DM, Sherman BM \& Santen RJ. FSH-secreting pituitary adenomas: Stimulation and suppression studies in two patients. Journal of Clinical Endocrinology and Metabolism 197643 650-657.

14 Snyder PJ \& Sterling FH. Hypersecretion of LH and FSH by a pituitary adenoma. Journal of Clinical Endocrinology and Metabolism 197642 544-549.

15 Daneshdoost L, Gennarelli TA, Bashey HM, Savino PJ, Sergott RC, Bosley TM et al. Recognition of gonadotroph adenomas in women. New England Journal of Medicine 1991324 589-594.

16 Snyder PJ. Gonadotroph cell adenomas of the pituitary. Endocrine Reviews $19856552-563$

17 White MC, Daniels M, Newland P, Thompson CJ, Cook D, Dewar J et al. LH and FSH secretion and responses to GnRH and TRH in patients with clinically functionless pituitary adenomas. Clinical Endocrinology 199032 681-688.

18 Koide Y, Kugai N, Kimura S, Fujita T, Kameya T, Azukizawa M et al. A case of pituitary adenoma with possible simultaneous secretion of thyrotropin and follicle stimulating hormone. Journal of Clinical Endocrinology and Metabolism 198254 397-403.

19 Sullivan MW, Stewart-Akers A, Krasnow JS, Berga SL \& Zeleznik AJ. Ovarian responses in women to recombinant follicle-stimulating hormone and luteinizing hormone (LH): A role for LH in the final stages of follicular maturation. Journal of Clinical Endocrinology and Metabolism 199984 228-232.

20 Woodruff TK \& Mather JP. Inhibin, activin and the female reproductive axis. Annual Review in Physiology $199557219-244$.

21 Hwang PLH, Ng CSA \& Cheong ST. Effect of normal contraceptives on serum prolactin: A longitudinal study in 126 normal premenopausal women. Clinical Endocrinology $1986 \quad 24$ 127-130.

Received 8 March 2000

Accepted 12 June 2000 